\title{
Deneysel Egzersiz Uygulamasının Yaşlılık Sürecinde Etkileri
}

\author{
Ülker Tunca ${ }^{1 *}$, Arzu Yalçın $^{1}$, Mustafa Saygın ${ }^{1}$, Hamit Yaşar Ellidağ $^{2}$ \\ ${ }^{1}$ Süleyman Demirel Üniversitesi, Tıp Fakültesi, Fizyoloji ABD, Isparta, Türkiye \\ ${ }^{2}$ Süleyman Demirel Üniversitesi, Tıp Fakültesi, Temel Bilimler Bölümü, Fizyoloji ABD Isparta, Türkiye \\ email:ulkertnc31218@gmail.com, arzuyalcin07@gmail.com, fizyolog@gmail.com \\ Orcid: 0000-0003-2734-0059 \\ Orcid: 0000-0002-7738-5477 \\ Orcid: 0000-0003-4925-3503 \\ Orcid: 0000-0002-7511-2547 \\ *Sorumlu Yazar / Corresponding Author: Sorumlu Yazar: ulkertnc31218@gmail.com
}

Gönderim Tarihi / Received: 05.09.2019

Kabul Tarihi / Accepted: 23.12.2019

DOI: $10.34087 /$ cbusbed.616028

\section{$\ddot{\mathbf{O z}}$}

\begin{abstract}
Amaç: Ilımlı yüzme egzersizine tabi tutulan orta yaş ve yaşlanma sürecine giren sıçanlarda lenfositlerdeki DNA hasarının comet analizi ile serum iskemik modifiye albümin (İMA)'leri ve toplam antioksidan seviye (TAS), toplam oksidan seviye (TOS)'leri arasındaki ilişkiyi karşılaştırmak.

Yöntem: Yaptığımız çalışmada 32 adet erkek Sprague-Dawley (350-500 gr) 11-12 aylık ve 15-16 ay arası yaşlı sıçanlar kullanıldı. Çalışmada her grupta 8'er adet sıçan olmak üzere 4 grup oluşturuldu. Gruplar; kontrol (K1; 11 12 aylık), Egzersiz (E1; 11-12 aylık), Kontrol (K2; 15-16 aylık), Egzersiz (E2; 15-16 aylık) olarak adlandırılmıştır. Yüzme egzersizi, $30 \mathrm{dk} /$ gün, 5 gün/hafta, toplam 8 hafta orta dereceli egzersiz eğitimi verildi. Egzersiz eğitimi sonrası ötenazi yapıldı ve oksidatif strese bağlı DNA kırıklarının tespitinde kullanılacak olan comet analizi için kan örnekleri toplandı. Serum örneklerinin biyokimyasal analizleri yapılmak üzere kanlar 10.000 rpm santrifüje edildi.

Bulgular: Comet analizinde E1 $-\mathrm{K} 1$ gruplar arasinda istatistiksel olarak anlamlı fark bulundu $(\mathrm{p}=0,001)$ ve E1 grubunda comet skoru azald1. E2-K2 egzersiz grupları arasında da istatistiksel olarak anlaml fark bulundu $(p=0,001)$ ve E2 grubunda comet skoru azaldı. Egzersiz gruplarına bakıldığında (E1-E2) istatistiksel olarak anlamlı fark bulunmadı ( $>0.005$ ). Serum örneklerinde ise, İMA, iskemik modifiye albümin/albümin oranı (İMAO) gruplar arasında anlamlı bir fark bulunmadı $(\mathrm{p}>0.005)$. Serum TAS, TOS, OSİ sonuçlarında egzersiz-2 kontrol-2 arasında bir fark bulunmuştur $(\mathrm{p}=0.004)$ ve egzersiz-2 grubunda antioksidan artış1 kontrol-2 göre artış göstermiştir.

Sonuç: Fiziksel egzersiz eğitiminin, antioksidan kapasitedeki artışla ilişkili olan lenfositlerdeki DNA hasarına karşı koruyucu etkileri olduğu gösterildi. Sonuçlar yaşlanma sürecinde veya orta yaş süreçlerinde yapılanacak düzenli 1lımlı aerobik egzersizin yaşam kalitesinin artışında etkin olabileceği düşünüldü.
\end{abstract}

Anahtar Kelimeler: Yüzme Egzersizi, COMET, Yaşlanma, İMA.

\footnotetext{
Abstract

Objective: To compare the relationship between serum ischemic modified albümin (IMA) and total antioxidant level (TAS), total oxidant level (TOS) and DNA analysis of lymphocyte damage in middle aged and aging rats subjected to moderate swimming exercise.

Methods: In this study, 32 male Sprague-Dawley rats (350-500 g) were used between 11-12 months and 15-16 months old rats. In this study, consisted of 4 groups of 8 rats in each group. Groups; control (K1; 11-12 months), Exercise (E1; 11-12 months), Control (K2; 15-16 months), Exercise (E2; 15-16 months). Swimming training, 30 minutes / day, 5 days / week, a total of 8 weeks of moderate exercise training was given. After exercise training, euthanasia was performed and blood samples were collected for comet analysis which would be used to detect DNA fractures due to oxidative stress. Blood samples were centrifuged at 10,000 rpm for biochemical analysis of serum samples.

Results: Comet analysis showed a statistically significant difference between the E1 $-\mathrm{K} 1$ groups $(\mathrm{p}=0.001)$ and the comet score decreased in the E1 group. There was a statistically significant difference between the E2-K2 exercise groups $(\mathrm{p}=0.001)$ and comet score decreased in the E2 group. There was no statistically significant difference between exercise groups (E1-E2) ( $p>0.005)$. In serum samples, IMAR, IMA-Albumin ratio did not differ between the groups $(p>0.005)$. Serum TAS, TOSOSI results showed a difference between exercise-2 control-2 $(p=0.004)$ and antioxidant increase in exercise- 2 group increased compared to control-2.
} 
Conclusion: Physical exercise training has been shown to have protective effects against DNA damage in lymphocytes associated with an increase in antioxidant capacity.Results It was thought that regular moderate aerobic exercise to be performed during the aging process or middle age processes may be effective in improving the quality of life.

Keywords: Swimming Exercise, COMET, Aging, IMA.

\section{Giriş}

Canlıların tümünde ortak olan kompleks, çok faktörden etkilenen ve evrensel olan yaşlanma; organizmanın hücre, doku, organ ve sistemlerce zamanın ilerlemesi ile ortaya çıkan moleküler yolaklardaki hasar ile desteklenmiş dejeneratif işlemlerin birikmesi ile karakterize, geriye dönüşün olmadığı yapısal ve fonksiyonel değişimlerin tümüne verilen süreçtir [1, 2].

Yaşlanma beraberinde metabolizmanın yavaşlaması, detoksifikasyon yetersizliği, zararlı etkilere sebep olan serbest radikallerin artışına, hücre çoğalma ve proliferasyonun yavaşlamasına, apoptoz düzenlenmesinin azalmasına, stres savunma genlerinin ifadesinde azalma olmasına ve sonuç olarak vücudun homeostazisi sağlama kapasitesinde düşüşlerin görüldüğü bir durumdur [3].

Düzenli fiziksel aktivitede bulunma yaşlı yetişkinlerin de dâhil olduğu nüfus içerisinde herkesin zihinsel ve fiziksel sağlığı için önemlidir. Düzenli egzersiz ve fiziksel aktivite, yaşlanma sürecinde bazı hastalık ve sakatlıkların oluşma riskini azaltabileceği, hatta ilaç benzetmesi ile stratejik bir yaklaşım yapılabilmektedir. Bundan dolayı sağlık uzmanları yaşlı bireylerin sağlığını korumada maksimum yarar sağlamak için yeterli yoğunluk, hacim ve süreye sahip egzersiz uygulamaları ile her gün aktif olmaları gerektiğini söylemektedirler [4].

Egzersize bağlı adaptasyonlar özellikle kas iskelet sistemi, vücut kompozisyonu, kardiyorespiratuvar ve metabolizma üzerinde açıkça görülmektedir. Egzersiz depresyon ve kaygı durumlarının azaltılmasında, stresle gelen kas gerimininin azaltılmasında ve endojen opioidlerin etkileri ile depresyondan uykuya kadar merkezi sinir sisteminde birçok alanda orta şiddetli ve düzenli yapılmak şartı ile pozitif yönde yardımcı olduğu bildirilmektedir [5]. Yaşlanma ile gelen beyin kan akımı üzerindeki değişiklikler, azalmış bilişsel işlev, nörodejenerasyon ve demansın başlangıcı olarak ortaya çıkacaktır. Egzersiz bilişsel gerilemeyi önlemek veya geciktirmek için bir strateji olabilir [6]. Egzersiz kastaki iyileştirilmiş glukoz taşınması ile insülin duyarlılığının artışı, kan basıncının azalması, otonomik tonus inervasyonun gelişimi, sistem düzeyinde inflamasyonun azalması, dengesiz pıhtılaşmanın azalması, koroner kan akışının artırıcı etki ile kardiyak fonksiyonu geliştirmesi ve endotel fonksiyonun iyileşmesi gibi bir seri olumlu neticeler sergilenir [4].

Düzenli antrenmanların birçok faydası bulunmakla beraber, şiddet düzeyinin artması egzersizin reaktif oksidatif türlerinin (ROT) üretimini artırarak oksidatif hasar oluşturabilir. Kronik egzersizin ise oksidatif stresle bağlantılı hastalıklara karşı organizmayı savunduğu ve lipid peroksidasyon aktivitesini, protein ve DNA hasarını azalttığı rapor edilmiştir [7].

Bununla birlikte, egzersiz oksidatif strese yol açsa da, hormesis teorisine göre endojen antioksidan savunmadaki artış, adaptif mekanizmalarla antioksidanda artışa, daha zararsız çevreye doğru bir kayma isteği ile artan stres direncinin indüklenmesi ve sonuç olarak daha iyi bir yaşam sürecinin yolunu açabileceğini söyler [8]. $\mathrm{Bu}$ bilgiler 1şı̆̆ında, antioksidan enzimlerin ekspresyonunu arttırdı̆̆ 1 için egzersizin kendisinin antioksidan olarak görev yapmaktadır denilebilir [4]

Kan dokusunda bakılacak serum albümin ve albüminin kimyasal modifikasyonu oksidatif stres beliteçlerinden biridir. İskemi ve hipoksi gibi durumlarda modifikasyon sonucu iskemik modifiye albümin (İMA) artmış olarak karşımıza çıkar [9].

$\mathrm{Bu}$ çalışmamızda 8 haftalık düzenli ılımlı yüzme egzersizine tabi tutulan orta yaş ve yaşlanma sürecine giren sıçanlarda lenfositlerdeki DNA hasarı ve onarım kapasitesindeki etkilerinin comet assay testi, serum İMA, albümin ve serum toplam antioksidan seviye (TAS), toplam oksidan seviye (TOS)'leri oksidatif stres indeksi (OSI) kan dokusundaki değişimlerin araştırılması amaçlandı.

\section{Materyal ve Metot}

$\mathrm{Bu}$ çalışma; Süleyman Demirel Üniversitesi Tıp Fakültesi Temel Tıp Bilimleri Bölümü Fizyoloji Ana Bilim Dalı Araştırma Laboratuvarında gerçekleştirildi. Burdur Mehmet Akif Ersoy Üniversitesi Hayvan Deneyleri Yerel Etik Kurul Başkanlığı'nın ile etik kurul izni alındı (12.12.2018/476)

Çalışmada 32 adet erkek Sprague-Dawley (350-500 gr) 11-12 aylık ve 15-16 aylık yaşlı sıçanlar kullanıldı. Çalışma, 8'er adet sıçanın randomize dağıtımı ile 4 grup yapıldı. Gruplar;

\section{Kontrol-K1= 11-12 aylık sıçan \\ Egzersiz-E1= 11-12 aylık sıçan \\ Kontrol-K2=15-16 aylık siçan \\ Egzersiz-E2=15-16 aylık sıçan olmak üzere ayrıldı.}

Sıçanlar 12 saat aydınlık 12 saat karanlık olacak şekilde, $\%$ 55-60 nem oranl1, 24-26 ${ }^{\circ} \mathrm{C}$ sabit 1s1lı ortamda takip edildi. Yem (Standart Sıçan Yemi, Korkutelim Yem, Türkiye) ve sıvılar ad libitum olarak verildi. Altlıkları 
haftalık, aldıkları sıvılar ise gün aşırı değiştirildi. Sıçanlar Euro type-4 kafesler içerisinde barındırıldı.

\subsection{Egzersiz Çalıșma Planı}

Günlük yüzme egzersizi, büyük bir su tankında $[100 \mathrm{~cm}$ $(\mathrm{L}) \times 60 \mathrm{~cm}(\mathrm{G}) \times 80 \mathrm{~cm}(\mathrm{H})]$ su sicaklığ $32 \pm 2^{\circ}$ C'de olacak tarzda kullanılan termostat ile su sıcaklığını sabit tutularak gerçekleştirildi. Su derinliği 40 santimetreye ayarlandı. Siçanlar ayaklarıyla zemine dokunma suretiyle kendilerine destek olmamasina dikkat edildi. Hayvanlar, altı ila sekiz adet gruplar halinde yüzdürüldü.

Yüzme programı uyum ve eğitim olmak üzere iki aşamadan oluşmaktadır. Adaptasyon için son günde 30 dakika olacak şekilde kademeli adaptasyon eğitimine ilk hafta 10 dakika olarak başlatıld1. Adaptasyon, suya bağlı stresin aşırı fizyolojik değişimlere neden olmaması için kullanıldı. İlk uygulama sonrası adaptasyon süresi ile orant1lı olarak bir hafta sonrası asıl egzersiz eğitimine başland. Eğitim süresi 30 dakika sabit tutularak sıçanlar yüzdürüldü. $30 \mathrm{dk} / \mathrm{gün}, 5$ gün/hafta yoğunluğunda eğitim periyodu 8 hafta sürecek tarzda orta şiddetli egzersiz uygulandı [10]. Egzersiz her gün aynı saatte (09:00 ile 11:00 arasında) gerçekleştirildi. Yüzdükten sonra sıçanlar kuru havlu ile kurutuldu ve ortam elektrikli isitici ile sicak tutuldu.

\subsection{Comet Analizi}

Sıçanların sakrifikasyonu sonunda alınan kan numuneleri oksidatif stres kaynaklı DNA kırıklarının tespiti için kullanılacak olan comet analizi için $500 \mu \mathrm{l}$ heparinize kan $+100 \mu$ l dimethyl sulphoxide (DMSO) + $400 \mu \mathrm{l}$ Roswell Park Memorial Institute (RPMI) 1640 Medium olarak cryo tüpler içinde hazırlandı ve çalışılıncaya kadar $-80^{\circ} \mathrm{C}$ 'de saklandı.

Comet analizi yapmak için uygun koşullarda cryo tüplerde bekletilen numunelerin ilk olarak hücreler 37 ${ }^{\circ} \mathrm{C}$ 'de su banyosunda çözünmeleri beklendi. Daha sonra $\%$ 0,5'lik düşük erime noktalı agaroz (LMA) ile süspanse edilip daha önceden üzeri \% 0,5 'lik normal erime noktasına sahip agaroz (NMA) ile kaplanmış lam üzerine aktarıldı. Katılaştıktan sonra 3. tabaka olarak üzerine yine \% 0,5'lik LMA ilave edildi. Bu üç tabakalı jel hazırlandıktan sonra hücreler deterjanlı solüsyon içerisinde (lizis tamponu $20 \mu \mathrm{g} / \mathrm{ml}$ of proteinase) 1 saat parçalanması beklendi [11].

Elektroforez sonrasında lam nötralizasyon tamponu ile yıkanıp kurutuldu ve florokrom $(50 \mu \mathrm{l}$ of $8 \mu \mathrm{l} / \mathrm{m}$ ethidium bromide) bir boya ile boyand. Etidyum bromürle boyanan preparatlar Olympus marka florasan mikroskop altında 400X objektifte incelendi. Sonuçlar kuyruk uzunluğu, kuyruk yoğunluğu ve kuyruk momenti cinsinden değerlendirildi. Görsel skor sistemine göre 5 farklı DNA hasarı sınıfı göz önünde bulundurularak 0-4 ölçeğinde incelenmiştir $(0=$ hasar yok, 4 = maksimum hasar, resim1). Bahsedilen tüm işlemler, çevre kaynaklı DNA hasarını önlemek amacıyla karanlık ortamda yapıldı [12].

\subsection{Albumin Kobalt Bağlama Tahlili - İskemik Modifiye Albümin (IMA, İMA)}

Serum iskemik modifiye albümin (IMA), daha önce tarif edildiği gibi eksojen kobaltı bağlamak için albüminin biyokimyasal özelliklerine dayanarak kolorimetrik deney ile ölçülmüştür. İskemi modifiye serum albümin konsantrasyonu, bir serum örneğine bilinen miktarda kobalt (II) eklenmesi ve bağlanmamış kobaltın (II) ditiyotreitol (DTT) kullanılarak kolorimetrik deneyle ölçülmesiyle belirlenebilir. Dolayısıyla, albümin bağlı kobaltın seviyesi ile renk oluşumunun yoğunluğu arasında ters bir ilişki vardır. Co (II) albümin bağlama protokolü için hazırlıklar, 50/ l'lik bir 1 gm / 1 kobalt klorür çözeltisine 2001 örneklerin serumu ilavesi sonrası kuvvetli karıştırma ve 10 dakikalık inkübasyonu içermektedir. Ditiyotreitol (50 litre, $1.5 \mathrm{~g} / 1$ solüsyon) eklenir ve karıştırılır 2 dakika inkübasyon sonrası ise $1.0 \mathrm{ml}, 9.0 \mathrm{~g} / 1 \mathrm{NaCl}$ çözeltisi eklenir.

470 nm'de tahlil karışımın absorbansını Spektrofotometre (UV1201, Shimadzu, Kyoto, Japonya) kullanılarak okundu. Lippi ve ark. iskemi modifikasyon albümin standardize edilmiş hesaplaması kullanılmıștır [13].

\subsection{Toplam Antioksidan- Oksidan Durumunun} Ölçülmesi

Serum toplam antioksidan seviye (TAS) - toplam oksidan seviye (TOS) - oksidatif stres indeksi (OSI) Erel tarafından geliştirilen yeni bir otomatik ölçüm yöntemi kullanılarak belirlenmiştir [14]. Serum TASTOS sonuçlarını almak için ticari kitler kullanılmıştır. Spektrofotometrik olarak ölçülebilen renk yoğunluğuna göre klorometrik analizler yapılıp hesaplanmıştır [15].

\subsection{Oksidatif Stres İndeksi}

TOS'un TAS'ye oran1, oksidatif stres derecesinin bir göstergesi olan oksidatif stres indeksini (OSI, OSI) vermektedir. Hesaplamayı yapmak için, TAS sonuç birimi mmol Trolox equiv/l, $\mu$ mol equiv/1'e dönüştürüldü ve OSİ değeri, aşağıdaki formüle göre hesaplandi; OSİ = [(TOS, $\mu \mathrm{mol} / \mathrm{l})$ / (TAS, mmol Trolox equiv / 1) x 100] [14,15].

\section{6. İstatistiksel Analiz}

İstatistiksel değerlendirmeler SPSS 22.0 for Windows programı kullanılarak yapıldı. Grupların tanımlayıcı istatistikleri ortalama ve standart sapma (sd) şeklinde verilmiştir. Değerlendirme öncesinde, verilerin normal dağılım gösterip göstermedikleri Kolmogorov-Simirnov testi ile bakıldı. Normal dağılım gösteren verileri tek yönlü ANOVA testi ile gruplar karşıllaştırıldı. İstatistiksel anlamlılık değeri \% 95 güven aralığında $\mathrm{p}<0.05$ olarak alındı.

\section{Bulgular ve Tartışma}

Çalışmamızda yüzme egzersizi bitimi ile deney hayvanları dekapite edildikten sonra kan numunelerinden yapılan DNA hasar analizi dağılımı tablo 1'de verildi. 
Tablo - 1. Comet analizlerinin gruplar arası ortalama ve standart sapma değerleri

\begin{tabular}{|l|c|}
\hline & $\begin{array}{l}\text { Ortalama ve Standart Sapma } \\
\text { Değerleri }\end{array}$ \\
\hline Kontrol $-1(n=6)$ & $224.00 \pm 28.12$ \\
\hline Kontrol $-2(n=6)$ & $175.66 \pm 41.93$ \\
\hline Egzersiz $-1(n=6)$ & $45.83 \pm 26.50$ \\
\hline Egzersiz $-2(n=6)$ & $55.83 \pm 35.35$ \\
\hline
\end{tabular}

E1 - K1 gruplar arasında istatistiksel olarak anlamlı fark bulundu ( $\mathrm{p}=0,001)$ ve E1 grubunda comet skoru azald1. E2 - K2 egzersiz grupları arasında da istatistiksel olarak anlaml fark bulundu $(\mathrm{p}=0,001)$ ve E2 grubunda comet skoru azaldı. Egzersiz gruplarına bakıldığında (E1-E2) istatistiksel olarak anlamlı fark bulunmadı $(\mathrm{p}>0.005)$.

\begin{tabular}{|c|c|c|c|c|c|c|}
\hline \multirow[t]{2}{*}{ Gruplar } & \multicolumn{2}{|c|}{$\begin{array}{c}\text { TAS } \\
(\text { mmol Trolox equivalents } \\
\text { /L) }\end{array}$} & \multicolumn{2}{|c|}{$\begin{array}{c}\text { TOS } \\
(\mu \mathrm{mol} \mathrm{H} 2 \mathrm{O} 2 \text { Equiv./L) }\end{array}$} & \multicolumn{2}{|c|}{ OSI. OSİ } \\
\hline & Ortalama $\pm \mathrm{SS}$ & p değeri & Ortalama $\pm \mathrm{SS}$ & p değeri & Ortalama \pm SS & p değeri \\
\hline Kontrol 1 & $1.44 \pm 0.13$ & & $9.08 \pm 3.76$ & & $6.22 \pm 2.34$ & \\
\hline Egzersiz 1 & $1.43 \pm 0.12$ & & $5.82 \pm 2.16$ & & $4.03 \pm 1.43$ & \\
\hline Kontrol 2 & $1.58 \pm 0.17$ & & $9.76 \pm 2.58$ & & $6.15 \pm 1.46$ & \\
\hline Egzersiz 2 & $1.46 \pm 0.17$ & & $4.94 \pm 1.53^{\mathrm{a}}$ & a: 0.003 & $3.38 \pm 1.07^{\mathrm{a}}$ & a: 0.004 \\
\hline
\end{tabular}

Değerler Ortalama \pm SS olarak sunulmuştur. Gruplar ve biyokimyasal belirteçlerin sonuçları arasındaki ilişkiler tek yönlü ANOVA ile değerlendirilmiștir. (TAS: Toplam antioksidan seviyeleri, TOS: Toplam oksidan seviyeleri, OSİ: Oksidatif stres indeksi).
Serum TOS, OSİ belirteçlerine göre Egzersiz 2'nin Kontrol 2 gruplar arası karşılaştırılmasında istatistiksel anlamlı fark bulunmuştur ( $\mathrm{p}<0,05)$. Egzersizin yaşlanma üzerinde reaktif ürünlerin oluşumunda azaltıcı etkinliğinden bahsedebiliriz (Tablo - 2).

Tablo - 3. IMA, IMAR ve Albumin sonuçları

\begin{tabular}{|l|c|c|c|c|c|c|}
\hline \multirow{2}{*}{ Gruplar } & \multicolumn{2}{|c|}{ IMA } & \multicolumn{2}{c|}{ IMAO } & \multicolumn{2}{c|}{ Albümin } \\
\hline & Ortalama \pm SS & p değeri & Ortalama \pm SS & p değeri & Ortalama. \pm SS & p değeri \\
\hline Kontrol 1 & $0.46 \pm 0.013$ & & $0.18 \pm 0.03$ & & $2.51 \pm 0.38$ & \\
\hline Egzersiz 1 & $0.44 \pm 0.008$ & NS & $0.16 \pm 0.013$ & NS & $2.71 \pm 0.23$ & NS \\
\hline Kontrol 2 & $0.45 \pm 0.017$ & & $0.16 \pm 0.02$ & & $2.75 \pm 0.30$ & \\
\hline Egzersiz 2 & $0.45 \pm 0.016$ & NS & $0.15 \pm 0.01$ & NS & $2.96 \pm 0.20$ & NS \\
\hline
\end{tabular}

Değerler Ortalama \pm SS olarak sunulmuştur. Gruplar ve Pereira ve ark., kan ve iskelet dokusunda aşırı egzersiz biyokimyasal belirteçlerin sonuçları arasındaki ilişkiler tek yönlü ANOVA ile değerlendirilmiştir. (İMA: İskemik Modifiye albümin, İMAO: iskemik modifiye albümin/ albümin oranı).

Tablo -3'de serum İMA İMAO ve Albümin sonuçlarını görmekteyiz. Sonuçlara göre gruplar arası istatistiksel olarak anlamlı bulunmamıştır $(\mathrm{p}>0,05)$. Egzersiz etkinliğini kan dokusu üzerinde comet analizi, İMA faktörü ve oksidatif stres parametreleri ile değişimlerini incelediğimiz bu çalışmada egzersizin yaşlanma ile getireceği reaktif oksidatif ürün birikimini azaltacağını ve DNA hasar üzerine olumlu etkisiyle sağlıklı yaşlanma için önemli stratejik tedavilerden olabileceğ kan dokusu üzerinde etkinliği ile göstermiş olduk.

Düzenli egzersizin, fonksiyonel performansı iyileştirme, morbiditeyi azaltma ve yaşlılar arasındaki tüm ölüm nedenleri üzerindeki en önemli yaşam tarzı etkilerinden biri olduğu gösterilmiştir. Araştırmamızda yaşlı sıçanlar üzerinde yapılan düzenli orta düzey yüzme egzersiz uygulamasının lenfositlerdeki DNA hasarı üzerindeki etkilerini azaltarak, oksidatif stresi engelleyebileceği bulundu.

ile DNA hasar ilişkisine değinmişlerdir. Oksidatif stresin artışını her iki dokuda da ortaya koymuşlardır [16]. Sandri ve ark., Pereira grubunu onaylar çalışmaları ile yoğun egzersizin DNA hasarını kas dokusunda arttığını göstermişlerdir [17]. Selman ve ark., kısa süreli egzersiz uygulamasının lenfositler üzerindeki DNA hasar ilişkisinin olmadığını göstermişlerdir [18]. Hayvan çalışmalarından elde edilen bulgular şunu göstermektedir ki, düzenli egzersizin DNA hasarını azalttığını ve DNA onarımını arttırdığını söyleyebiliriz. $\mathrm{Bu}$ nedenle çalışmamızda düzenli aerobik uygulaması olarak yüzme egzersizini tercih ettik. Orta 1lımlı düzenli egzersiz uygulamasının yaşlı sıçanlarda etkinliğini gözlemlendi.

Soares ve ark., yaşlılık üzerine yaptıkları araştırmalarında egzersiz uygulamasının DNA hasarı üzerinden vücuttaki değişimleri izlemişlerdir. Kronik egzersizin hem ROS üretimini azaltarak hem de antioksidan kapasiteyi artırarak oksidatif stres ve hasarı azalttığ 1 ve çeşitli organ ve sistemlerde mitokondri verimliliğini arttırdığını açıklayan diğer verilere kendi yaptıkları çalışma ile de destek vermişlerdir. 16 haftalık kombine fiziksel egzersiz uygulamasına aldıkları deneklerde kan örneklerinden lenfositlerdeki DNA 
hasarı ve onarım kapasitesindeki etkilerini tespit etmişlerdir [19]. DNA onarımı açısından bakılan Radak ve ark., sekiz haftalık koşu bandı tatbiki sonrası orta yaş ve yaşlı farelerin kas dokularındaki artmış olduğu ortaya koymuşlardır [20]. İnsan çalışmalarına bakıldığında Hartmann ve ark., aerobik-anaerobik eşiğin üzerinde fiziksel aktivite sonrası lökositlerdeki değişimi DNA hasar ve onarım kapasitesi arasındaki ilişki incelenmiştir.

Değişimin onarım yönünde etkileyebileceği bildirilmiştir. Egzersizin DNA hasar ve onarım ilişkisini incelerken Comet ile değişimleri ortaya konulabileceği söylenilmiştir [21]. Bizim çalışmamızda yaşlanma ve yaşlı olarak ele aldığımız sıçanlara düzenli yaptırılan orta şiddetli yüzme egzersizin DNA hasar üzerinde etkinliğini olumlu yönde değiştirebileceğini comet analizi ile ortaya koyduk. Yukarıdaki bahsi geçen çalışmalarla uyumlu olarak düzenli ve orta şiddetli olmak şartı ile yaşlanma sürecinde egzersizin protektif etkinliği olabileceğini söyleyebiliriz.

Egzersiz uygulamalarında comet analizinin bir belirteç olarak kullanımı artarak, egzersizin zararı ve yararına yönelik pek çok çalışmada comet analizinin kullanılabileceği ortaya konulmuştur. Comet analizi egzersiz uygulaması sonrası redoks değişimleri hakkında bizleri yönlendirebilecek bir test olabileceği ve yapılan çalışmalarda DNA hasarı kan üzerinden tahlil edilmesi reaktif oksijen türlerinin vücutta nasıl düzenlenebileceği hakkında bilgi verecektir. Buna dair çalışmalar bizim bu konu üzerindeki araştırmamızda yönlendirici olmuştur [22, 23].

Serum TAS, TOS seviyeleri egzersiz uygulamalarında Kocabaş ve ark. yaptıkları voleybol sporu ilgilenen sporcu bireylerin oksidatif stres durumu ve akut egzersiz etkinliği için bakılmıştır. TAS düzeyi voleybol maçı sonrasında önemli ölçüde etkilenmedi. TOS seviyesi ise azaldığı tespit edilmiştir [24]. Bir başka egzersiz uygulamasında oksidatif stres belirteçlerinden MDA, SOD, CAT, GPx, GST değerlendirmesinde egzersize ek takviye uygulamasının daha etkin olduğu söylenilmiştir [25]. Bizim çalışmamızda serum TAS, TOS, OSİye baktığımızda ise $15-16$ aylık yaşlanma sürecindeki gruplar arasında egzersiz -2'nin kontrol -2'e göre anlamlı bir fark ile antioksidan yönünde artış göstermiştir. Egzersizin yaşlanmaya karşı gelişecek biriken oksidan maddelere karşı savunma yapabileceğini söyleyebiliriz. Ortamda reaktif oksijen türlerinin $\mathrm{H} 2 \mathrm{O} 2, \mathrm{OH}^{-}, \mathrm{O}^{-}$oluşması İMA oluşumunda etkisi olduğu düşünülmektedir. İMA, iskemik olayların sonras1 doku iskemisi ve özellikle oksidatif stresi gösteren bir belirteçtir [26, 27]. Meng ve ark. yüzme egzersizin akut ve kronik uygulamasında myokard hasarı üzerinde serum İMA değerinde kronik uygulamanın yapıldığı grupta düşüş gösterdiği bildirilmiştir [28]. Kaya ve ark yaptıkları çalışmada ağır egzersiz uygulaması sonrası İMA seviyeleri artmıştır.
Böylece ağır egzersizin akut etkilerinden biri olarak İMA söylenebilir [29]. Kurban ve ark. tip-II diyabet hastalar1 üzerinde kronik düzenli egzersiz uygulamasının İMAve serum TAS, TOS OSI belirteçleri ile değişimlerini incelemişlerdir. Egzersizin, tip-2 DM'de İMA seviyelerinin artmasını önlediğini ve bu hastalarda artan TAS düzeylerinden kaynaklanabileceğini ve bu hastalarda iskemi riskini azalttığını göstermişlerdir [30]. Ancak çalışmamızdaki serum İMA, İMAO sonuçları yukardaki çalışmalarla paralel sonuçlar vermemiştir. Comet analizi ile serum OSI OSİ bulguları birbiri ile korele iken İMA için aynı şeyi söyleyemeyiz. Egzersiz yaşlılık ilişkisinde kan dokusu parametreleri hakkında daha geniş çalışmalar yapılmasının ihtiyacı ortaya çıkmaktadır.

\section{Sonuç}

Comet analizi ökaryotik hücrelerde DNA stabilitesini ölçmek için basit ve güvenilir bir yöntemdir, ancak egzersiz bilimi ile ilgili çalışmalarda az kullanıldığı görülmüştür. Aslında, tahlil sadece kan lenfosit hücrelerinde kullanılmıştır, ancak egzersizin DNA modifikasyonu ve redoks biyolojisi üzerindeki etkilerini tam olarak değerlendirmek için kas gibi farklı hücre tiplerini incelemeye de ihtiyaç vardır.

Düzenli yüzme egzersiz eğitiminin, antioksidan kapasitesindeki artışla ilişkili olan lenfositlerdeki DNA hasarına karşı koruyucu etkilere neden olduğu gösterildi. Serum TOS, OSİ bulguları da comet analizi ile paralel seyir gösterdi. Sonuçlar yaşlanma sürecinde veya orta yaş süreçlerinde yapılanacak düzenli 1 lımlı yüzme egzersizlerin yaşam kalitesinde olumlu etkileri olabileceğini düşündürmektedir.

5. Kaynaklar

1. Karasu, Ç, Biyolojik yaşlanma teorileri: oksidatif stresin rolü, Turkiye Klinikleri Journal of Medical Science, 2008, 28, 1-11.

2. Wagner, K.H, Cameron-Smith, D, Wessner, B, Franzke, B, Biomarkers of aging: from function to molecular biology, Nutrients, 2016, 8, 338.

3. Azzu, V, Valencak, T.G, Energy metabolism and ageing in the mouse: a mini-review, Gerontology, 2017, 63, 32736.

4. Galloza, J, Castillo, B, Micheo, W, Benefits of exercise in the older population, Physical Medicine and Rehabilitation Clinics of North America, 2017, 28, 659-69.

5. Çakır, B, Sıçanlarda orta dereceli yüzme egzersizin aku ve kronik stres yanıtına etkisi, İstanbul Marmara Üniversitesi 2005.

6. Barnes, J.N, Exercise, cognitive function, and aging, Advances in Physiology Education, 2015, 39, 55-62.

7. Emekçi, S, Akut yüzme egzersizi yaptırılan ratlarda timokinon uygulamasinin apoptozis ve DNA hasari üzerine etkisi, Van Yüzüncü Yı Üniversitesi, 2016.

8. Pingitore, A, Lima, G.P, Mastorci, F, Quinones, A, Iervasi, G, Vassalle, C, Exercise and oxidative stress: potential effects of antioxidant dietary strategies in sports, Nutrition (Burbank, Los Angeles County, Calif), 2015, 31, 916-22.

9. Roy, D, Quiles, J, Gaze, D.C, Collinson, P, Kaski, J.C, Baxter, G.F, Role of reactive oxygen species on the formation of the novel diagnostic marker ischaemia modified albumin, Heart (British Cardiac Society), 2006, 92, 113-4. 
10. Seo, D.Y, Lee, S.R, Kim, N, Ko, K,S, Rhee, B.D, Han, J, Humanized animal exercise model for clinical implication. European Journal Of Physiology, 2014, 466, 1673-87.

11. Collins, A.R, The comet assay for DNA damage and repair: principles, applications, and limitations, Molecular Biotechnology, 2004, 26, 249-61.

12. Correa, M.D.S, Gelaleti, R.B, Bento, G.F, Damasceno D.C, Peracoli, J.C, DNA damage in Wistar Kyoto rats exercised during pregnancy, Acta Cirurgica Brasileira, 2017, 32, 388-95.

13. Lippi, G, Montagnana, M, Salvagno, G.L, Guidi, G.C, Standardization of ischemia-modified albumin testing adjustment for serum albumin, Clinical Chemistry And Laboratory Medicine, 2007, 45, 261-2.

14. Erel, $O$, A novel automated direct measurement method for total antioxidant capacity using a new generation, more stable ABTS radical cation, Clinical Biochemistry, 2004, 37, 277-85.

15. Erel, O, A new automated colorimetric method for measuring total oxidant status, Clinical Biochemistry, 2005, 38, 1103-11.

16. Pereira, B.C, Pauli, J.R, Antunes, L.M, de Freitas, E.C, de Almeida, M.R, de Paula Venancio, $V$, et al, Overtraining is associated with DNA damage in blood and skeletal muscle cells of Swiss mice, BMC Physiology, 2013, 13, 11.

17. Sandri, M, Carraro, U, Podhorska-Okolov, M, Rizzi, C Arslan, P, Monti, D, et al, Apoptosis, DNA damage and ubiquitin expression in normal and mdx muscle fibers after exercise, FEBS Letters, 1995, 373, 291-5.

18. Selman, C, McLaren ,J.S, Collins, A.R, Duthie, G.G, Speakman, J.R, Antioxidant enzyme activities, lipid peroxidation, and DNA oxidative damage: the effects of short-term voluntary wheel running, Archives of Biochemistry And Biophysics, 2002, 401, 255-61.

19. Soares, J.P, Silva, A.M, Oliveira, M.M, Peixoto, F, Gaivao, I, Mota, M.P, Effects of combined physical exercise training on DNA damage and repair capacity: role of oxidative stress changes, Age (Dordrecht, Netherlands), 2015, 37, 9799.

20. Radak, Z, Naito, H, Kaneko, T, Tahara, S, Nakamoto, H, Takahashi, R, et al, Exercise training decreases DNA damage and increases DNA repair and resistance against oxidative stress of proteins in aged rat skeletal muscle, European Journal of Physiology, 2002, 445, 273-8.

21. Hartmann, A, Plappert, U, Raddatz, K, Grunert-Fuchs, M, Speit, G, Does physical activity induce DNA damage? Mutagenesis, 1994, 9, 269-72.

22. Pittaluga M, Sgadari A, Dimauro I, Tavazzi B, Parisi P, Caporossi D. Physical exercise and redox balance in type 2 diabetics: effects of moderate training on biomarkers of oxidative stress and DNA damage evaluated through comet assay. Oxidative medicine and cellular longevity. 2015;2015:981242.

23. Kara M, Ozcagli E, Fragkiadaki P, Kotil T, Stivaktakis PD, Spandidos DA, et al. Determination of DNA damage and telomerase activity in stanozolol-treated rats. Experimental and therapeutic medicine. 2017;13(2):614-8.

24. Kocabas, R, Namiduru, E.S, Bagceci, A.M, Erenler, A.K, Karakoc, O, Orkmez, M, et al, The acute effects of interval exercise on oxidative stress and antioxidant status in volleyball players, The Journal Of Sports Medicine And Physical Fitness, 2018, 58, 421-7.

25. Göktepe M. Günay M. Quercetin uygulamasının egzersiz, serbest radikal ve antioksidan enzim düzeyler üzerine etkisi, International Journal of Science Culture and Sport, 2014, 1, 775-788.

26. Sbarouni, E, Georgiadou, P, Kremastinos, D.T, Voudris, V., Ischemia modified albumin:Is this marker of ischemia ready for prime time use?,The Hellenic Journal of Cardiology, 2008, 49, 260-266.

27. Roy, D, Quiles, J, Gaze, D.C, Collinson, P, Kaski, J.C, Baxter, G.F., Role of reactive oxygen species on the formation of the novel diagnostic marker ischemia modified albumin, Heart, 2006, 92, 113-114.

28. Meng, D, Li, P, Huang, X, Jiang, M.H, Cao, X.B. Protective effects of short-term and long-term exercise preconditioning on myocardial injury in rats, Journal Of Applied Physiology, 2017, 33, 531-4.

29. Kaya A. Sporcu Egzersizinin Kardiyak Etkilerinin Biyokimyasal Parametreler ile Değerlendirilmesi. Atatürk Üniversitesi Sağlık Bilimleri Enstitüsü, Yüksek lisans tezi, danışman Prof. Dr. Ebubekir BAKAN, Erzurum, 2014.

30. Kurban, S, Mehmetoglu, I, Yerlikaya, H.F, Gonen, S, Erdem, S, Effect of chronic regular exercise on serum ischemia-modified albumin levels and oxidative stress in type 2 diabetes mellitus, Endocrine Research, 2011, $36,116-23$

http://edergi.cbu.edu.tr/ojs/index.php/cbusbed isimli yazarın CBU-SBED başlıklı eseri bu Creative Commons Alınt1-Gayriticari4.0 Uluslararası Lisansı ile lisanslanmıştır. 